medRxiv preprint doi: https://doi.org/10.1101/2020.12.15.20248240; this version posted December 16, 2020. The copyright holder for this preprint (which was not certified by peer review) is the author/funder, who has granted medRxiv a license to display the preprint in It is made available under a CC-BY 4.0 International license .

\title{
$1 \quad$ Predicting Success of Phase III Trials in Oncology
}

2 Meta-analysis of phase II and phase III trials initiated between 2003 and 2012 to generate a

3 decision analytical model predicting success of future phase III trials

4

5 Stephan Hegge ${ }^{1, \#}, \mathrm{PhD}$, Markus Thunecke ${ }^{2}, \mathrm{PhD}$, Matthias Krings ${ }^{2}, \mathrm{PhD}$, Léonard Ruedin ${ }^{3}$,

6 MSc, Jan Saputra Müller ${ }^{4}$, MSc, Paul von Bünau³, PhD

7

$8 \quad{ }^{1}$ Hegge Holding UG, Kopernikusstr. 24, 10247 Berlin

9 2Catenion $\mathrm{GmbH}$, Münzstrasse 18, 10278 Berlin, Germany

10 3idalab GmbH, Potsdamer Straße 68, 10785 Berlin, Germany

$11 \quad{ }^{4}$ AskBy GmbH, Boxhagener Str. 18, 10245 Berlin

$13 \quad{ }^{\#}$ corresponding author

Email: StephanHegge@gmx.de

Word Count: 3493 
medRxiv preprint doi: https://doi.org/10.1101/2020.12.15.20248240; this version posted December 16, 2020. The copyright holder for this preprint (which was not certified by peer review) is the author/funder, who has granted medRxiv a license to display the preprint in

\section{Key Points}

Question: What is the probability of success (PoS) for single phase III (PhII)I trials in oncology?

Findings: We developed a model allowing to predict the PoS of single PhIll trials in oncology with a predictive performance of $73 \%$ pp and demonstrated that qualitative factors such as strength of Phll knowledge and sponsor R\&D strength can be captured in quantitative scores that have significant predictive power.

Meaning: The model can help study sponsors to analyze and amend planned clinical trials, and investors to choose where to invest best.

\section{Abstract}

Importance: We developed a model predicting the probability of success (PoS) for single planned or ongoing PhIII trials based on information available at trial initiation. Such a model is highly relevant for study sponsors to capture risk and opportunity on a trial-to-trial basis through trial optimization, and for investors to select drugs whose trial design match their investment strategy.

Objectives: To predict the outcome of planned or ongoing PhIll trials in oncology, given publicly available prior information

Design, Setting, Participants: Predictive modeling using publicly available data for 360 completed PhIII and 1240 Phll studies initiated between 2003 and 2012. Success and failure of PhIll studies were modeled using Bayesian logistic regression model.

Main Outcome Measures: Predicted PoS of individual PhIll trials based on a Bayesian model calibrated on publicly available data translated into 16 composite scores. Those scores cover aspects such as trial design, indication, number of patients, phase II (PhII) study outcomes, experience of sponsor at time of trial initiation, and others. 
medRxiv preprint doi: https://doi.org/10.1101/2020.12.15.20248240; this version posted December 16,2020 . The copyright holder for this preprint (which was not certified by peer review) is the author/funder, who has granted medRxiv a license to display the preprint in It is made available under a CC-BY 4.0 International license .

41 Results: The model allows to calculate the PoS distribution - including credible intervals -

42 for a PhIll trial in oncology. The predictive performance was determined using an area under

43 the receiver-operator curve (AUROC), resulting in an overall performance of $73 \%$ opP (mean

44 AUROC). We identified two key factors contributing to the predictive performance of the

45 model: quality and strength of Phll data and experience of the sponsor at the time of study

46 initiation.

47 Conclusion and Relevance: We describe the generation and application of a statistical model predicting the PoS for individual PhIll trials in oncological indications with unprecedented predictive performance. Compared to other approaches, this is the first study generating a fully transparent model resulting in trial-specific PoS distributions. Moreover, we have shown that qualitative concepts such as Phll knowledge or sponsor R\&D strength can be captured in quantitative scores and that these scores have a high predictive power. 
medRxiv preprint doi: https://doi.org/10.1101/2020.12.15.20248240; this version posted December 16, 2020. The copyright holder for this preprint (which was not certified by peer review) is the author/funder, who has granted medRxiv a license to display the preprint in

\section{Introduction}

In recent years, predictive algorithms have become ubiquitous across a wide range of industries, such as logistics - e.g. Amazon's predictive shipping ${ }^{1}$ - or information retrieval e.g. Google's predictive search algorithm². By combining information from a vast number of sources in an objective, unbiased manner, predictive algorithms can outperform human decision making with respect to accuracy and speed at marginal cost. Even in the public sector, political decision makers have become increasingly aware of the importance of accurate predictions and have started evaluating different approaches in forecasting tournaments ${ }^{3}$. Predictive algorithms can aid decision makers in the pharmaceutical industry as well. However, so far, adoption has been limited. The current decision making process, from discovery to clinical development phases, is characterized by a series of decision points defined by formal go/no-go criteria ${ }^{4}$ that relate to the available clinical data. This process is implemented to aid executives as it reflects regulatory requirements for each indication. However, it has been demonstrated that decisions based on real world cases vary greatly, ranging from absolutely 'go' to absolutely 'no-go' due to subjective interpretation of identical data $^{5}$.

We argue that predictive algorithms can be employed for improving and rationalizing decision making in Pharma, particularly in clinical trials representing the most crucial and expensive centerpiece of drug development. Predictive algorithms based on Big Data have demonstrated that they are able to aid or even outperform drug developers and physicians when it comes to predicting either patient accrual rates in clinical trials ${ }^{6,7}$, or optimal cancer rehabilitation $^{8}$, or supportive care interventions ${ }^{8}$.

Trial decision making for any drug in clinical development has far-reaching implications. On one hand, hundreds to thousands of patients are recruited to test the effects, each of them hoping to benefit from the new drug. On the other hand, sponsors risk tens to hundreds of million Dollars on trials that may or may not demonstrate the drug's effect ${ }^{9}$. It is therefore in the interest of sponsors to terminate failures early, without compromising on the quality of 
medRxiv preprint doi: https://doi.org/10.1101/2020.12.15.20248240; this version posted December 16, 2020. The copyright holder for this preprint (which was not certified by peer review) is the author/funder, who has granted medRxiv a license to display the preprint in It is made available under a CC-BY 4.0 International license.

81

82

clinical trials or terminating successful agents, and - most importantly - without exposing clinical trial subjects to unnecessary risk ${ }^{10}$. It is also in the interest of patients to participate in trials that have a strong chance to achieve a positive outcome.

Success and failure rates in pharmaceutical drug development are described by several sources, ranging from commercial benchmarking providers like BioMedTracker ${ }^{11,12}$ to academic papers ${ }^{13-16}$.

Still, no established method exists to predict the probability of success (PoS) for an individual clinical trial; in fact, there is no clear definition for trial success and failure. Hence current approaches ${ }^{11-15}$ focus on determining the average attrition rates from phase to phase - so called phase transitions counts (PTC) - during drug development resulting in historical success rates (hSRs). Phase transitions - and hence hSRs - are either assessed on an

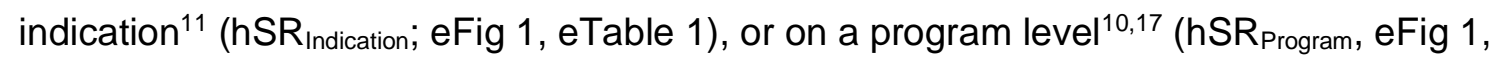
eTable 1). It has become gold standard in trial planning and portfolio management to take hSRs and use them as forward-looking estimates of PoS. Moreover, using hSR as gauge for forward-looking PoS is limited to factors that allow for straightforward stratification. Drivers that are more complex in nature, such as the knowledge a sponsor has accumulated from prior phases, cannot be analysed using simple hSRs. This approach has far-reaching implications in decision making for several reasons:

a) hSRs are historic, past transition rates, however they are naively used as forwardlooking probabilities, without a statistical evaluation of their predictive power

b) hSRs are averages. Thus, applying these as forward-looking PoS to specific individual trials will systematically overestimate the PoS of riskier than average drug development programs, while underappreciating the PoS of particularly well conducted low-risk programs

c) hSR-based PoS values are typically used as point estimates without credible intervals ${ }^{11}$. This can lead to a false sense of confidence, and falsely informed decisions - such as terminating a drug that would work and be safe in favor of 
medRxiv preprint doi: https://doi.org/10.1101/2020.12.15.20248240; this version posted December $16,2020$. The copyright holder for this preprint (which was not certified by peer review) is the author/funder, who has granted medRxiv a license to display the preprint in It is made available under a CC-BY 4.0 International license .

continuing a drug that is ineffective or unsafe - when rating the PoS of one program higher than another

d) Neither of the hSR approaches consider individual trials, but are limited to indications ${ }^{11}$, drug programs ${ }^{10}$ or even entire therapeutic areas ${ }^{17}$

112 Here we present an approach providing forward looking PoS estimates for individual PhIII

113 trials in oncology based on publicly available data. Firstly, all potentially relevant parameters

114 were classified and translated into numerical or categorical data. Secondly, we identified and

115 quantified correlations between each parameter and trial outcome. Thirdly, we developed

116 and calibrated a Bayesian algorithm for predicting trial outcomes, which provides a full

117 posterior distribution. Fourthly, we have shown that complex qualitative factors such as Phll

118 knowledge or sponsor R\&D strength can be modeled using quantitative scores and that

119 these scores are indeed significantly predictive. This approach allows decision-makers to

120 capture risk and opportunity on a trial-to-trial basis, and helps trial sponsors and planners to

121 identify and mitigate trial- and indication-specific risks. 
medRxiv preprint doi: https://doi.org/10.1101/2020.12.15.20248240; this version posted December 16, 2020. The copyright holder for this preprint (which was not certified by peer review) is the author/funder, who has granted medRxiv a license to display the preprint in

\section{Materials and Methods}

\section{Data Sources}

125 ClinicalTrials.gov (CT.gov) is a publicly accessible database run by the United States

126 National Library of Medicine at the National Institutes of Health ${ }^{18}$. It served as a starting point

127 for our analysis as it is the largest registry for clinical trials to date providing general

128 characteristics and outcome information of about 283,000 (as of January 2018) federally

129 and privately supported clinical trials. $47 \%$ of studies recruit patients outside the US, $36 \%$ of

130 trials are recruiting in the US only, and 6\% recruit patients in both, US and non-US locations,

131 while $11 \%$ do not provide that information ${ }^{18}$.

132 To complement for potentially publicly available information not listed on CT.gov we used the

133 European Clinical Trial Database ${ }^{19}$, JAPIC Clinical Trials Information ${ }^{20}$, PubMed $^{21}$ and Adis

$134 R \& D^{22}$ (ADIS). We used PubMed to identify publications associated with each given trial.

135 ADIS is a database for drug development gathering all available information (in vitro and in

136 vivo experiments, preclinical data, clinical trial outcomes, chemistry, conference posters,

137 conference abstracts, press releases etc.) for a given compound.

\section{Study Sample}

We queried the database of CT.gov ${ }^{18}$ (>183,000 trials by April 2014) and applied filters to identify a sample of novel therapeutics (i.e., new chemical entities (NCEs) or novel biological entities (NBEs)) for which a Phlll study in oncology had been initiated between 01.01.2003 and 01.03.2012 (Fig 1). Filter criteria excluded generics, biosimilars, reformulations, radiotherapy, and combination therapies of two or more non-novel therapeutics. Celltherapies, non-therapeutic agents, such as diagnostic tools, contrast agents and supportive care approaches were also not considered. We removed all duplicated records.

\section{Technical Implementation}

147 For MCMC sampling, we used the software package JAGS version 4.3. All other 
medRxiv preprint doi: https://doi.org/10.1101/2020.12.15.20248240; this version posted December 16, 2020. The copyright holder for this preprint (which was not certified by peer review) is the author/funder, who has granted medRxiv a license to display the preprint in It is made available under a CC-BY 4.0 International license.

\section{Results}

Database

151 ClinicalTrials.gov is the largest registry of clinical trials database with $>183,000$ registered

152 trials at the time of query (Fig 1, I). Strict application of exclusion criteria resulted in 360 PhIII trials across 37 oncology indications (Fig 1, IV). The 111 NBEs and NCEs associated with these PhIII studies served as a starting point for the complementary analysis, which aimed to gather all publicly available PhIl and PhIII information associated with the original set of 360 PhIll studies by means of searching for the drug name, the trial identifier, trial names and its synonyms. We searched in the European and Japanese trial registries EudraCT and JAPIC, scanned published literature using PubMed.gov, company homepages, and checked Adis R\&D, a database for drug research and development (Fig 1, V). This approach gave rise to 1240 Phll studies, 488 publications, and 111 ADIS data entries, respectively, with detailed information about Phll and Phlll study outcomes, endpoint measures, study design, actual patient population etc. (eTables 1-3). Please note, $\mathrm{Phl}$ results were not considered for this proof-of-principle analysis, given Phl studies are less well defined with regard to patient stratification (mixed patient population with regard to tumor type, tumor stage, line of treatment) and endpoint measures. We defined trial success by meeting all primary endpoints (see eTable 3 for detailed classification).

Scoring approach for predictive modeling

The key step in predictive modeling is to construct informative (predictive) scores from the available raw data. To this end, we employed a hybrid approach that combines (a) expertdriven design of complex scores to incorporate human judgement and experience and (b) a purely data-driven approach to assigning weights to variables and then selecting the most predictive variables. The group of domain experts consisted of eight consultants with an academic life science background and several years of work experience in pharma R\&D. Notably, expert input was not employed with regard to individual trials (which would lead to biased results), but exclusively in the structural design of the scoring methodology. Fig 2 
medRxiv preprint doi: https://doi.org/10.1101/2020.12.15.20248240; this version posted December 16, 2020. The copyright holder for this preprint (which was not certified by peer review) is the author/funder, who has granted medRxiv a license to display the preprint in

176 provides a conceptual overview of this approach illustrated by an exemplary drug X, which is

177 developed in three different indications A, B, and C (Fig 2A). We identified a battery of

178 information available at a given point in time (Fig 2A, time of assessment, vertical grey line)

179 to assess the probability of success for a given PhIII trial of interest (TOI, blue box). We

180 classified all available information into time-dependent variables (Fig 2B, eTable 1), drugrelated characteristics (Fig 2C, eTable 2) and trial-specific characteristics (Fig 2D, eTable 3).

Within each of these categories we created composite scores combining weight and magnitude of information. All composites were broken down to objective and quantifiable elements (Fig 2B i-iii). We developed unbiased decision matrices for variables that offered no direct read-out from the database (e.g. Relatedness between Phll and PhIII TOI, eFig 2). In total, we created three classes of parameters comprising 16 composite scores (see eTables 2-4) based on 82 variables. Consequently, each PhIII trial is described by a unique set of descriptors, allowing the generation of a trial-specific prediction.

\section{Generation of predictive model}

The overall approach to predictive modeling is a dynamic Bayesian logistic regression ${ }^{23}$.

More specifically, the log-odds of the binary target variable (Fig 3, Outcome of TOI S either success or failure) is modeled as a linear function of the independent variables with a Gaussian prior for each variable $k$ 's weight $\alpha$ (Fig 3A) resulting in a trial specific PoS $\Theta$. The coefficients (weights) are estimated in a Bayesian approach using a Markov Chain Monte Carlo $(\mathrm{MCMC})^{24}$ simulation to generate samples from the posterior of each parameter (Fig 3B); the final estimate is the posterior mean (Fig 3C).

\section{Training and evaluation of the predictive model}

As a performance metric, we use the Area under the Receiver-Operator Characteristic $(A U R O C)^{25}$. To account for the time structure in the data (Phlll trial initiation spanning 20032012), we use a dynamic modeling approach with regard to (a) the construction of the independent variables from raw data (Fig 4A), (b) variable selection (Fig 4B) and (c) overall performance evaluation (Fig 4C). Regarding step (a), this means that in the computation of 
medRxiv preprint doi: https://doi.org/10.1101/2020.12.15.20248240; this version posted December 16, 2020. The copyright holder for this preprint (which was not certified by peer review) is the author/funder, who has granted medRxiv a license to display the preprint in It is made available under a CC-BY 4.0 International license.

scores only such information is used that was available at the time point of the respective PhIII trial's initiation date (eTable 1). For variable selection (b) and overall performance evaluation (c) we adopt a time-series cross-validation strategy.

\section{(Ir-)Relevance of variables}

The predictive performance of single composite scores can be calculated for 15 out of the 16 composite scores that we designed, i.e. all scores but novelty of MoA (Fig 4A). When applying the AUROC performance metric, we found positive correlation - mean AUROC $>55 \%$, ranging up to $64 \%$ AUROC - with success or failure for the metrics SPIIK, Company R\&D strength, number of subjects in trial, designations, trial type and prior registrations of the drug in other indications.

We found no correlation - AUROC $>45 \%$ and $<55 \%$ - with success or failure for the metrics modality, indication, geography, and involvement of Big Pharma.

\section{Model selection}

The best full predictive risk model (PRM) was built based on the single composite scores with a positive contribution to the model, while scores without impact were omitted (Fig 4B). To arrive at the best PRM, we added - at each step - the variable producing the highest mean AUROC increase of the model (or the smallest decrease). The variables selected (Fig $4 \mathrm{~B})$ are those that bring the highest overall predictive performance, reported as the mean AUROC over five time-series cross-validation splits (Fig 4C, Fig 3S). Note that the predictive performance of the single scores is not strictly additive due to overlapping information.

\section{Overall model performance}

The performance of the model with the best combination is $73 \%$ opp and includes 12 variables (Fig 4C, eFig 3B, dotted line). In other words, confronted with one successful and one unsuccessful trial, using the PRM one will correctly identify the successful trial in $\sim 73 \%$ of the cases by picking the trial with the higher predicted PoS. 
medRxiv preprint doi: https://doi.org/10.1101/2020.12.15.20248240; this version posted December 16, 2020. The copyright holder for this preprint (which was not certified by peer review) is the author/funder, who has granted medRxiv a license to display the preprint in It is made available under a CC-BY 4.0 International license.

229 To illustrate the model's output on single trials, we elected to highlight the variables

230 characterizing exemplary clinical trials and to visually signify their influence on the PoS

231 prediction (Fig 5A). Consequently, we selected two clinical studies at different ends of the

232 spectrum, one with low mean PoS - gefitinib in treating patients with esophageal cancer that is progressing after chemotherapy, NCT01243398 ${ }^{26}$, Fig 5B - and one with high mean PoS trastuzumab emtansine versus capecitabine + lapatinib in participants with HER2-positive locally advanced or metastatic breast cancer (EMILIA), NCT00829166²7, Fig 5C.

The initiation dates of both studies were respectively March $2009^{26}$ for NCT01243398 and February $2009^{27}$ for NCT00829166. To mimic a real world PhIll decision point, the model goes back to the time before those particular PhIll were initiated, thereby only accessing data that were available then. The resulting PoS distributions are therefore built on $92 \mathrm{PhIII}$ studies and its corresponding Phll trials preceding initiation of NCT01243398 and NCT00829166.

242 According to our model, the PhIll trial in in esophageal cancer with gefitinib had a predicted mean $\mathrm{PoS}_{\text {Trial }}$ of $7.8 \%$ Pos with $95 \% \mathrm{cl}$ credible interval ranging from $\mathrm{PoS}_{\text {Trial }}=0.3 \%$ Pos to $67.2 \%$ pos at time of initiation. The study eventually failed to meet the primary endpoint median overall survival ${ }^{28}$ (Fig 5D). On the other hand, according to our model the PhIII trial in breast cancer with trastuzumab emtansine had a predicted mean PoS $\mathrm{S}_{\text {Trial }}$ of $88.6 \%$ Pos with $95 \% \mathrm{cl}$ credible interval ranging from $\mathrm{PoS}_{\text {Trial }}=19.6 \% \mathrm{Pos}$ to $99.6 \% \mathrm{Pos}$ at time of initiation. That clinical study was successful ${ }^{29}$ (Fig 5E), confirming the predicted high probability of success. 
medRxiv preprint doi: https://doi.org/10.1101/2020.12.15.20248240; this version posted December 16, 2020. The copyright holder for this preprint (which was not certified by peer review) is the author/funder, who has granted medRxiv a license to display the preprint in It is made available under a CC-BY 4.0 International license.

\section{Discussion}

250 Drug developers use historical success rates as forward-looking estimates to determine the

251 PoS of an individual trial to inform their decision making. These PoS rates are often adjusted

252 based on the opinion of subject matter experts, so-called Key Opinion Leaders (KOLs). For

253 more than 60 years studies ${ }^{30-32}$ have kept demonstrating that expert opinions are no better

254 than guessing, while in the last decade or so it was established that algorithms are able to

255 aid or even outperform drug developers and physicians when it comes to predicting patient

256 accrual rates in clinical trials ${ }^{33,34}$, optimal cancer rehabilitation, or supportive care

257 interventions ${ }^{8}$. Therefore, it is surprising that an industry praising rationale drug development

258 still takes decisions regarding investments, strategy, and science based on subjective expert

259 advice. While the traditional approach certainly has some merit, we argue that a data-driven

260 prediction can complement - if not quite replace - traditional methods such as KOL

261 interviews and hSR benchmarking. In particular, we have demonstrated that the

262 consideration of complex drivers of PhIII success such as the accumulated knowledge from

263 prior phases is not limited to the judgement of experts (KOLs), but can also be addressed in

264 an empirical data-driven manner using a sophisticated scoring approach presented in this

265 study.

\section{Discussion of results}

267 Employing several publicly available database s $^{18,21,22}$ we developed a predictive model generating forward-looking and trial-specific probability of success (PoS) distributions for PhIll trials in oncology.

The most relevant single composite scores contributing to the full PRM are Strength of Ph II Knowledge (SPIIK) (mean AUROC SPIIK $=64 \%$ ) and Company R\&D Strength at time of trial initiation (mean AUROC $_{\text {SPIIK }}=63 \%$, Fig. $4 A$ ).

The SPIIK includes the strength and relatedness of the combined Phll evidence that exists before starting the PhIII (Fig 2, eTable 2). Our use of a decision tree optimized for prediction allowed us to model the relevance of a combined Phll body of evidence to a particular PhIII 
medRxiv preprint doi: https://doi.org/10.1101/2020.12.15.20248240; this version posted December 16, 2020. The copyright holder for this preprint (which was not certified by peer review) is the author/funder, who has granted medRxiv a license to display the preprint in It is made available under a CC-BY 4.0 International license.

study and its design (eFig 2). The predictive performance of SPIIK alone confirms that the information building this composite score is relevant indeed. This is in line with both, common sense and regulatory guidance ${ }^{35}$, suggesting that the sum of Phll results are to some degree indicative for PhIll trial outcomes.

The sponsor's past track record in oncology (Company R\&D Strength) had the second largest predictive performance for PhIll studies. As this criterion includes both the number of past PhII and III studies in oncology as well as the outcomes, it essentially describes where an organization stands on the learning curve when it comes to designing studies in oncology. Noteworthy, this value is time-dependent to consider the situation on the day of trial initiation. There is a strong effect of having designed phase II and III studies that met their primary endpoints on the ability to do it again. Janssen, Celgene, and Genentech are the top 3 performers in this category of companies with at least 10 PhIll studies $(2003-2012)$ in our sample.

\section{The role of indication}

The factor 'indication' provides no additional value to the predictive risk model (Fig 4A, B). Notably, this is in line with expectations due to the technical bias in trial selection (Fig 1); We started our search with PhIll trials and only subsequently enriched with Phll trials associated with the selected PhIII trials. Therefore, we introduced a bias for drugs that made it into PhIII in at least one indication. Drugs exclusively developed in indications known for high failure rates (e.g. Pancreatic Cancer) ${ }^{14}$ hardly make it into a PhIll trial in the respective indication, hence PhIII trials in these indications are underrepresented in this proof of concept study.

\section{Novelty of $M O A$}

In order to factor in the degree of innovation brought about by the compounds investigated in PhIII, we designed a composite score taking into account the novelty of MoA. That composite score was excluded from the model, as the results of our attempt were not conclusive. On one hand, this is due to the complexity of embodying the qualitative nature of innovation into a quantitative variable. On the other hand, there is a lack of availability of systematic, 
medRxiv preprint doi: https://doi.org/10.1101/2020.12.15.20248240; this version posted December 16, 2020. The copyright holder for this preprint (which was not certified by peer review) is the author/funder, who has granted medRxiv a license to display the preprint in It is made available under a CC-BY 4.0 International license.

303

304

305

306

comprehensive data due to fundamental differences in the MoA classification schemes used and the level of information provided by companies (eTables 2 and 4 ).

\section{Comparison to other approaches}

Empirical studies of clinical trial success broadly fall into two categories: (i) retrospective descriptive analysis of success rates ${ }^{11,12,15,16,36,37}$ and (ii) predictive approaches to modeling clinical trial success ${ }^{10,38}$, as in the present study. From a statistical methodology point of view, retrospective descriptive studies focus on estimates of success rates computed from empirical binary (fail vs. success) $\mathrm{h}^{11,39}$. Confidence intervals for the reported PoS estimates are mostly not provided, with the exception of Wong $2018^{16}$ (standard errors).

Among the predictive studies, a much wider range of methodological approaches can be found in the literature (eTable 5). Schachter et al. ${ }^{10}$ employed a Bayesian Network, a highly flexible model class, which could potentially be used to formulate expressive bottom-up generative models of trial success. Still, the approach was limited at the time due to scarcity of available databases and lack of historical data ${ }^{40}$, resulting in a hold-out validation set too small $(n=14)$ to generate reliable outcomes. DiMasi et al. ${ }^{38}$ employ an unorthodox type of predictive model which uses a scoring logic to compute the predicted PoS for a given trial.

In contrast to others, we use a linear regression model to reduce overfitting and for ease of interpretation but calibrate parameters in a Bayesian fashion so that credible intervals for parameter estimates and a posterior predictive distribution is available for PoS estimates. This is the basis for downstream Monte-Carlo simulation of portfolio-level effects. Secondly, for model evaluation we use a time-series cross-validation strategy to analyze the performance over time, as more historic information becomes available. This analysis shows not only the mean AUROC on one data set but provides also variation and stability of predictive performance.

\section{Limitations of approach}


medRxiv preprint doi: https://doi.org/10.1101/2020.12.15.20248240; this version posted December 16, 2020. The copyright holder for this preprint (which was not certified by peer review) is the author/funder, who has granted medRxiv a license to display the preprint in It is made available under a CC-BY 4.0 International license.

328 The current algorithm is focused on oncology Phlll trials. For this proof of concept study, we 329 chose oncology over other therapeutic areas, because trial endpoints (mPFS and mOS) across all oncology indications are both, quantifiable and comparable in nature, providing a strong foundation for modeling approaches.

We excluded several non-standard modalities including the cellular therapies which are changing the treatment landscape as we speak. In principle, the algorithm is also prone to certain regulatory aspects (e.g. break through designations) that allow a development program to move from phase I (Phl) directly to PhIll or approval, respectively.

\section{Next steps \& outlook}

Based upon this proof of concept study, the model can potentially be expanded to (1) predict Phll trial outcomes based on data from pre-clinical and Phl studies, (2) therapeutic areas other than oncology (e.g. cardiovascular diseases), (3) incorporate more modalities (e.g. CAR T cells) for which a growing body of evidence is becoming available, and to (4) allow for the integration of non-public information available to drug developers (sponsors and investigators) in cooperation with the project teams.

\section{Conclusions}

The algorithm presented here can distinguish successful from unsuccessful trials with much greater confidence than any other publicly available approach reviewed ${ }^{10,12,14-17,38}$. The positive predictive value can be tuned up to $>80 \%$ ppv by accepting more false negatives (lower sensitivity). To our knowledge, this is the first approach allowing to quantitatively predict the probability of success for single trials. Our model uses publicly available information only, including that of prior trials with perhaps only remote relatedness to the trial in question, and then delivers a specific prediction for a given trial. In addition, the model is fully transparent, adaptive on a trial-to-trial basis, provides unprecedented granularity (e.g. consideration of line of treatment, or background therapy) and allows identification of factors negatively (or positively) influencing the trial's predicted $\mathrm{PoS}_{\text {Trial. }}$ 

medRxiv preprint doi: https://doi.org/10.1101/2020.12.15.20248240; this version posted December $16,2020$. The copyright holder for this
preprint (which was not certified by peer review) is the author/funder, who has granted medRxiv a license to display the preprint in It is made available under a CC-BY 4.0 International license .

354 Such an algorithm has a number of obvious applications of high medical, strategic and

355 financial value, quite apart from the ethical dimension of a doctor's decision to enroll patients

356 in a study. Both sponsors and investors involved in the field of oncology could benefit greatly

357 from a predictive algorithm assessing the prospects of a specific study, in particular by

358 - Supporting sponsoring companies to maximize success by designing their individual

$359 \quad$ studies based on the highest possible PoS Trial

360 - Helping investors determine the impact of Phlll outcomes on valuation. This is especially

361 relevant for those biotechs with a single PhIll asset. In addition, investors able to pursue different strategies could identify trials (and companies behind the studies) that match their investment strategy, e.g. pick-the-winner-drop-the-loser or vice versa. 
medRxiv preprint doi: https://doi.org/10.1101/2020.12.15.20248240; this version posted December 16, 2020. The copyright holder for this preprint (which was not certified by peer review) is the author/funder, who has granted medRxiv a license to display the preprint in It is made available under a CC-BY 4.0 International license.

364

365

366

367

368

369

370

371

372

373

374

375

376

377

378

379

380

381

382

\section{Acknowledgments}

SH drafted manuscript and figures, developed concept, acquired, analyzed and interpreted data, managed project. MT and MK supervised project, challenged concept, provided material and technical support, and critically reviewed manuscript. LR drafted manuscript and figures, acquired, analyzed and interpreted data. JSM developed, programmed and calibrated the model, retrieved data and critically reviewed manuscript. PvB developed the model, provided statistical analysis, interpreted data, drafted the manuscript, and supervised the project.

The authors thank Birte Arlt, Nina Heid and Jennifer Price for data curation and classification, Moritz Neeb and Daniel Kirsch for advice on data architecture and for co-developing of algorithms required for model, Gerrit Buurmann for strategic advice and for expert classification of trial data, and Johannes Zimmermann for critical review of manuscript.

Conflict of Interest: No conflicts of interest are declared for JSM, PvB, MK. SH, LR and MT have personal investments in several biotechnology companies. SH is Senior Director of Corporate Strategy at HotSpot Therapeutics Inc. and general manager of Hegge Holding UG. JSM is co-founder of AskBy GmbH. No funding bodies had any role in study design, data collection and analysis, decision to publish, or preparation of the manuscript. The authors were personally salaried by their institutions during the period of writing (though no specific salary was set aside or given for the writing of this paper). 
medRxiv preprint doi: https://doi.org/10.1101/2020.12.15.20248240; this version posted December 16, 2020. The copyright holder for this preprint (which was not certified by peer review) is the author/funder, who has granted medRxiv a license to display the preprint in perpetuity.

It is made available under a CC-BY 4.0 International license .

\section{References}

384 1. Spiegel JR, McKenna MT, Lakshman GS, Nordstrom PG. Method and System for 385 Anticipatory Package Shipping. Google Patents; 2013.

386 https://www.google.com/patents/US8615473.

387 2. Hu W, Zhang X, Bolivar A, Shoup RS. Predictive Algorithm for Search Box Auto388 Complete. Google Patents; 2015. http://www.google.com.pg/patents/US20150193449.

3893 3. Mellers B, Stone E, Murray T, et al. Identifying and cultivating superforecasters as a 390 method of improving probabilistic predictions. Perspect Psychol Sci. 2015;10(3):267-281.

391 4. Hedner T, Cowlrick I, Wolf R, Olausson M, Klofsten M. The changing structure of the pharmaceutical industry: perceptions on entrepreneurship and openness. 2011.

5. Cowlrick I, Hedner T, Wolf R, Olausson M, Klofsten M. Decision-making in the pharmaceutical industry: analysis of entrepreneurial risk and attitude using uncertain information. RD Manag. 2011;41(4):321-336.

6. London JW, Balestrucci L, Chatterjee D, Zhan T. Design-phase prediction of potential cancer clinical trial accrual success using a research data mart. J Am Med Inform Assoc. 2013;20(e2):e260-e266. doi:10.1136/amiajnl-2013-001846

7. Cheng SK, Dietrich MS, Dilts DM. Predicting Accrual Achievement: Monitoring Accrual Milestones of NCl-CTEP-Sponsored Clinical Trials. Clin Cancer Res. 2011;17(7):1947-1955. doi:10.1158/1078-0432.CCR-10-1730

8. Buffart LM, Kalter J, Chinapaw MJ, et al. Predicting OptimaL cAncer Rehabllitation and Supportive care (POLARIS): rationale and design for meta-analyses of individual patient data of randomized controlled trials that evaluate the effect of physical activity and psychosocial interventions on health-related quality of life in cancer survivors. Syst Rev. 2013;2(1):75.

9. Speich B, von Niederhäusern B, Schur N, et al. Systematic review on costs and resource use of randomised clinical trials shows a lack of transparent and comprehensive data. J Clin Epidemiol. December 2017. doi:10.1016/j.jclinepi.2017.12.018

10. Schachter AD, Ramoni MF, Baio G, Roberts TG, Finkelstein SN. Economic

411 Evaluation of a Bayesian Model to Predict Late-Phase Success of New Chemical Entities.

412 Value Health. 2007;10(5):377-385. doi:10.1111/j.1524-4733.2007.00191.x

413 11. Hay M, Thomas DW, Craighead JL, Economides C, Rosenthal J. Clinical development success rates for investigational drugs. Nat Biotechnol. 2014;32(1):40-51.

12. Thomas DW, Burns J, Audette J, Caroll A, Dow-Hygelund C, Hay M. Clinical Development Success Rates 2006-2015. BIO Industry Analysis. Amplion, Inc., Biomedtracker, Biotechnology Innovation Organization (BIO); 2016:1-26.

13. DiMasi JA, Grabowski HG. Economics of New Oncology Drug Development. J Clin Oncol. 2007;25(2):209-216. doi:10.1200/JCO.2006.09.0803

14. DiMasi JA, Reichert JM, Feldman L, Malins A. Clinical Approval Success Rates for Investigational Cancer Drugs. Clin Pharmacol Ther. 2013;94(3):329-335. doi:10.1038/clpt.2013.117 and economic returns. Am J Ther. 2014;21(1):26-34. 
medRxiv preprint doi: https://doi.org/10.1101/2020.12.15.20248240; this version posted December 16, 2020. The copyright holder for this preprint (which was not certified by peer review) is the author/funder, who has granted medRxiv a license to display the preprint in perpetuity.

It is made available under a CC-BY 4.0 International license .

16. Wong $\mathrm{CH}$, Siah KW, Lo AW. Estimation of clinical trial success rates and related parameters. Biostatistics. January 2018. doi:10.1093/biostatistics/kxx069

17. CMR International 2015 Pharmaceutical R\&D Factbook. Thomsen Reuters, Centre for Medicines Research (CMR) International; 2015.

18. Trends, Charts, and Maps - ClinicalTrials.gov. https://clinicaltrials.gov/ct2/resources/trends. Accessed April 4, 2014.

19. EudraCT. European Clinical Trial Database. https://eudract.ema.europa.eu/resultsweb/index.xhtml. Accessed December 4, 2014.

20. JAPIC Clinical Trials Information. JAPIC Clinical Trials Information.

http://www.clinicaltrials.jp/user/cteSearch.jsp;jsessionid=33025EAEEDA366B0FA4A26F45B 1F15DF. Accessed December 4, 2014.

21. pubmeddev. Home - PubMed - NCBI. https://www.ncbi.nlm.nih.gov/pubmed/. Accessed December 4, 2014.

22. Adis R\&D. www.springer.com. https://www.springer.com/gp/librarians/adis-r-d/7790. Accessed December 4, 2014.

23. Gelman A, Carlin JB, Stern HS, Dunson DB, Vehtari A, Rubin DB. Bayesian Data Analysis, Third Edition. CRC Press; 2013.

24. W.K. Hastings. Monte Carlo Sampling Methods Using Markov Chains and Their Applications. Biometrika. 1970;57(1):97-109.

25. Zweig $\mathrm{MH}$, Campbell G. Receiver-operating characteristic (ROC) plots: a fundamental evaluation tool in clinical medicine. Clin Chem. 1993;39(4):561-577.

26. Gefitinib in Treating Patients With Esophageal Cancer That is Progressing After Chemotherapy - Tabular View - ClinicalTrials.gov.

https://clinicaltrials.gov/ct2/show/record/NCT01243398. Accessed November 17, 2018.

27. A Study of Trastuzumab Emtansine Versus Capecitabine + Lapatinib in Participants With HER2-positive Locally Advanced or Metastatic Breast Cancer - Tabular View ClinicalTrials.gov. https://clinicaltrials.gov/ct2/show/record/NCT00829166. Accessed November 17, 2018.

28. Petty RD, Dahle-Smith A, Stevenson DAJ, et al. Gefitinib and EGFR Gene Copy Number Aberrations in Esophageal Cancer. J Clin Oncol. 2017;35(20):2279-2287. doi:10.1200/JCO.2016.70.3934

29. Diéras $V$, Miles $D$, Verma $S$, et al. Trastuzumab emtansine versus capecitabine plus lapatinib in patients with previously treated HER2-positive advanced breast cancer (EMILIA): a descriptive analysis of final overall survival results from a randomised, open-label, phase 3 trial. Lancet Oncol. 2017;18(6):732-742. doi:10.1016/S1470-2045(17)30312-1

30. Meehl PE. Clinical versus Statistical Prediction: A Theoretical Analysis and a Review of the Evidence. Minneapolis, MN, US: University of Minnesota Press; 1954. doi:10.1037/11281-000

31. Dawes RM, Faust D, Meehl PE. Clinical Versus Actuarial Judgment. Science. 1989;243:7. doi:10.1126/science.2648573

32. Grove WM, Zald DH, Lebow BS, Snitz BE, Nelson C. Clinical versus mechanical prediction: a meta-analysis. Psychol Assess. 2000;12(1):19-30. 
medRxiv preprint doi: https://doi.org/10.1101/2020.12.15.20248240; this version posted December 16, 2020. The copyright holder for this preprint (which was not certified by peer review) is the author/funder, who has granted medRxiv a license to display the preprint in It is made available under a CC-BY 4.0 International license .

33. Schroen AT, Petroni GR, Wang $\mathrm{H}$, et al. Challenges to accrual predictions to phase III cancer clinical trials: a survey of study chairs and lead statisticians of $248 \mathrm{NCl}$-sponsored trials. Clin Trials Lond Engl. 2011;8(5):591-600. doi:10.1177/1740774511419683

34. London JW, Balestrucci L, Chatterjee D, Zhan T. Design-phase prediction of potential cancer clinical trial accrual success using a research data mart. J Am Med Inform Assoc JAMIA. 2013;20(e2):e260-266. doi:10.1136/amiajnl-2013-001846

35. e-CFR. Electronic Code of Federal Regulations. Vol Title $21 \rightarrow$ Chapter I $\rightarrow$ Subchapter D $\rightarrow$ Part 312.; 1987. https://www.ecfr.gov/cgi-bin/textidx?SID=e05abc4c40756e7a19bd0ca2bc38b112\&mc=true\&node=pt21.5.312\&rgn=div5. Accessed February 12, 2019.

36. DiMasi JA, Reichert JM, Feldman L, Malins A. Clinical Approval Success Rates for Investigational Cancer Drugs. Clin Pharmacol Ther. 2013;94(3):329-335. doi:10.1038/clpt.2013.117

37. Smietana K, Siatkowski M, Møller M. Trends in clinical success rates. Nat Rev Drug Discov. 2016;15:379. doi:10.1038/nrd.2016.85

38. DiMasi J, Hermann J, Twyman K, et al. A Tool for Predicting Regulatory Approval After Phase II Testing of New Oncology Compounds. Clin Pharmacol Ther. 2015;98(5):506513. doi:10.1002/cpt.194

39. Dahlin E, Nelson GM, Haynes M, Sargeant F. Success rates for product development strategies in new drug development. J Clin Pharm Ther. 2016;41(2):198-202. doi:10.1111/jcpt.12362

40. Schachter AD, Ramoni MF. Clinical forecasting in drug development. Nat Rev Drug Discov. 2007;6(2):107-108. doi:10.1038/nrd2246 
medRxiv preprint doi: https://doi.org/10.1101/2020.12.15.20248240; this version posted December 16,2020 . The copyright holder for this preprint (which was not certified by peer review) is the author/funder, who has granted medRxiv a license to display the preprint in It is made available under a CC-BY 4.0 International license.

\section{Figures}

\section{Figure 1}

A) Screen

\begin{tabular}{|c|c|}
\hline \multicolumn{2}{|c|}{$\begin{array}{l}\text { I } \\
\text { 183,048 federally and privately } \\
\text { supported trials registered in } \\
\text { ClinicalTrials.gov }\end{array}$} \\
\hline $\begin{array}{l}\text { III } \\
\text { from additional trials } \\
\text { from sources }\end{array}$ & $\begin{array}{l}\mathbf{1 8 2 , 7 0 5} \text { trials were excluded } \\
161,168 \text { not in Phll/III or PhIII } \\
17,149 \text { not developed in oncology } \\
\text { 3,075 did not finish (complete, terminate) trial } \\
\text { within time frame } \\
543 \text { not within scope (e.g. contrast and diagnostic } \\
\text { agents, vaccines, generics, non-interventional) } \\
448 \text { technical aspects (e.g. duplicates) } \\
220 \text { less than } 50 \text { patients } \\
113 \text { unknown trial outcome }\end{array}$ \\
\hline
\end{tabular}

B) Data base creation

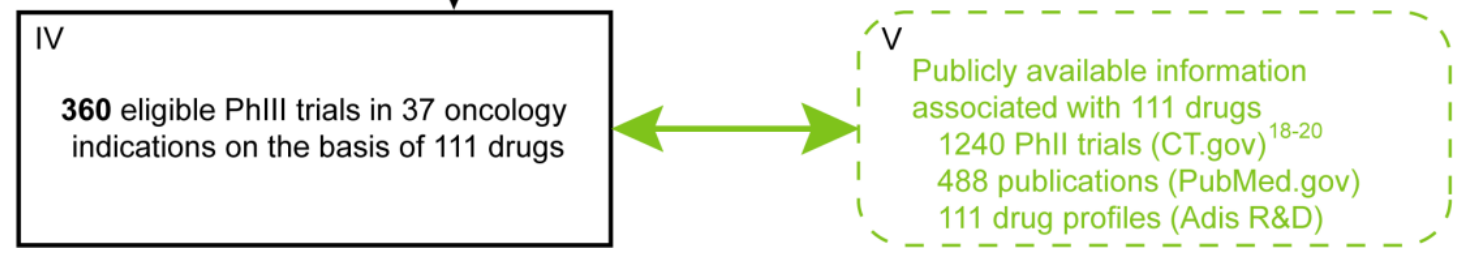

Consort flow diagram. (A) Screen. 360 eligible Phlll studies were identified screening 
medRxiv preprint doi: https://doi.org/10.1101/2020.12.15.20248240; this version posted December 16, 2020. The copyright holder for this preprint (which was not certified by peer review) is the author/funder, who has granted medRxiv a license to display the preprint in perpetuity.

It is made available under a CC-BY 4.0 International license .

\section{Figure 2}

A
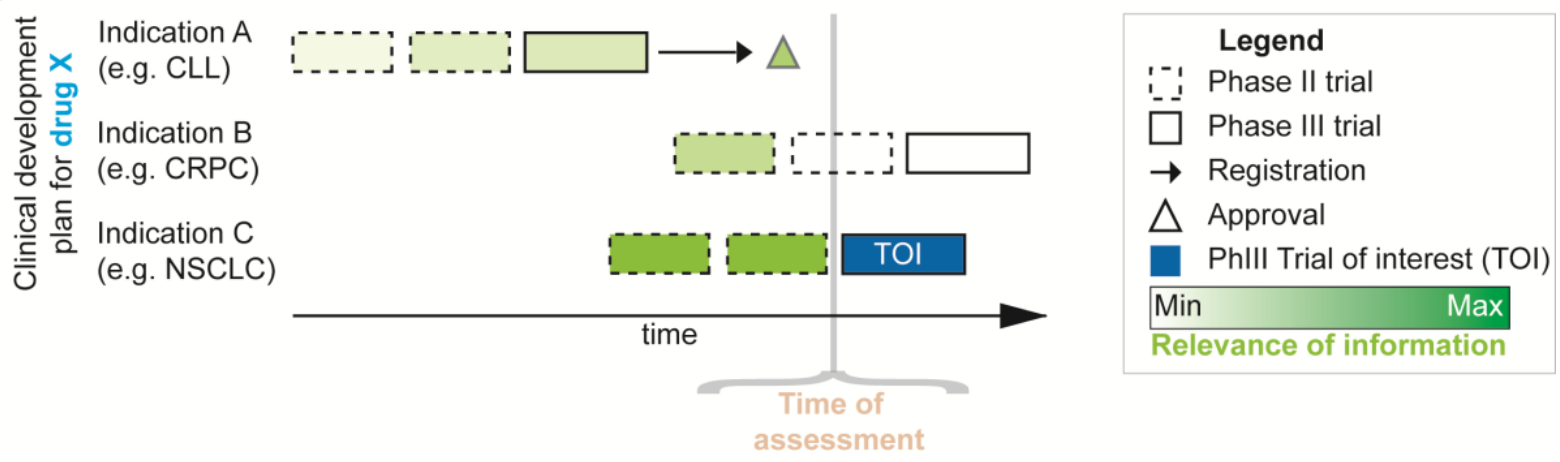

B (i)

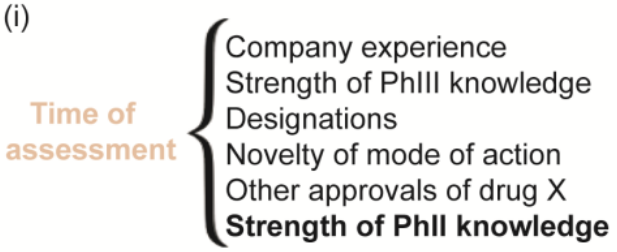

B (ii)

$\begin{aligned} & \text { Strength of } \\ & \text { Phll knowledge }\end{aligned}=\sum_{i=1}^{n}$ Relevance of

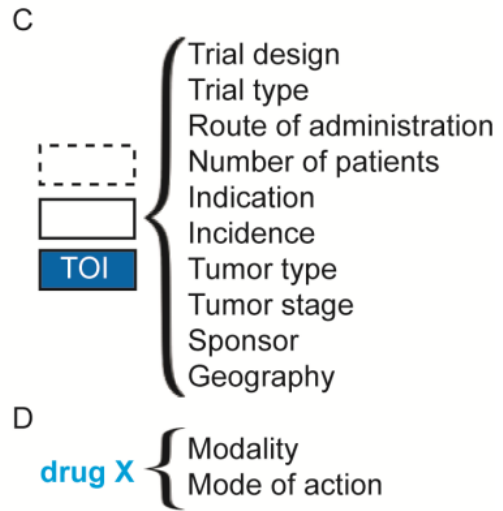

B (iii)
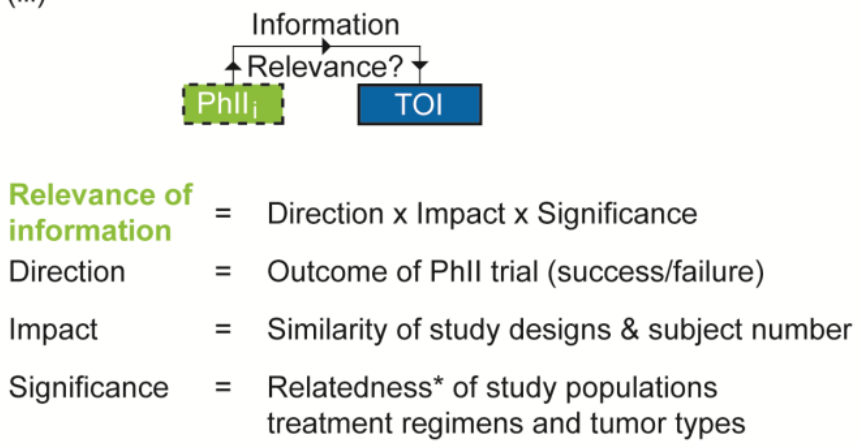

503 Identification, classification and weighting of variables relevant for PhIll trial assessment. (A)

504 Schematic clinical development plan for drug X developed by sponsor Y. At time of

505 assessment (vertical grey line) not all trials are completed (boxes with white fillings) hence

506 cannot contribute information for assessing the PoS of the trial of interest (TOI, blue). Trials

507 that were completed prior to the assessment carry information, but the relevance of this

508 information (shades of green) varies with regard to the specific characteristics of the TOI.

509 Generally speaking, the closer the patient population, the study design and the treatment

510 algorithm of a given trial with regard to the TOI, the higher its relevance. Note, the clinical

511 development plan (CDP) illustrates only elements, which are considered in the database. We

512 identified three large categories of parameters: Time-dependent variables (B), trial-specific

513 characteristics (C) and drug-related characteristics (D). (B.i) Time-dependent variables at 
medRxiv preprint doi: https://doi.org/10.1101/2020.12.15.20248240; this version posted December 16, 2020 . The copyright holder for this preprint (which was not certified by peer review) is the author/funder, who has granted medRxiv a license to display the preprint in It is made available under a CC-BY 4.0 International license.

514 time of assessment. Each of these variables is a composite score of several sub-variables,

515 as illustrated by the variable Strength of Phll knowledge (SPIIK, bold). (B.ii) Weighting of

516 relevant information exemplified by variable 'Strength of phase II knowledge'. SPIIK is a

517 composite of all relevant information (ROI) $i$ carried by all Phll studies completed at least 2

518 months prior to the time of assessment. The more Phll studies $i$ were completed, the

519 stronger the body of evidence. (B.iii) Definition of ROI. Any given Phll trial $i$ (green)

520 conducted with drug $X$ (not shown) carries information (black arrows) that are potentially

521 relevant for assessing the PoS of the TOI (blue). The ROI for a given trial $i$ is defined as the

522 product of three factors, each of which can be broken down into further subfactors, that may

523 even be further broken down (e.g. Relatedness, *see eFig 2 for details) until an objective and

524 quantifiable level of information is found. Note, that there is a unique ROI for each

525 combination of PhIl and TOI, thus a unique SPIIK for each TOI. (C) Characteristics of novel

526 therapeutic. (D) Inherent characteristics of trial of interest. 
medRxiv preprint doi: https://doi.org/10.1101/2020.12.15.20248240; this version posted December $16,2020$. The copyright holder for this preprint (which was not certified by peer review) is the author/funder, who has granted medRxiv a license to display the preprint in It is made available under a CC-BY 4.0 International license.

\section{Figure 3}

\begin{tabular}{|c|c|c|c|c|c|}
\hline Data & $\begin{array}{l}\text { Prior } \\
\text { distribution }\end{array}$ & $\begin{array}{l}\text { Coeffi- } \\
\text { cient }\end{array}$ & $\begin{array}{l}\text { Study } \\
\text { descriptor }\end{array}$ & $\begin{array}{l}\text { Pos of } \\
\text { TOl }\end{array}$ & $\begin{array}{l}\text { Outcome of } \\
\text { TOI }\end{array}$ \\
\hline
\end{tabular}

A

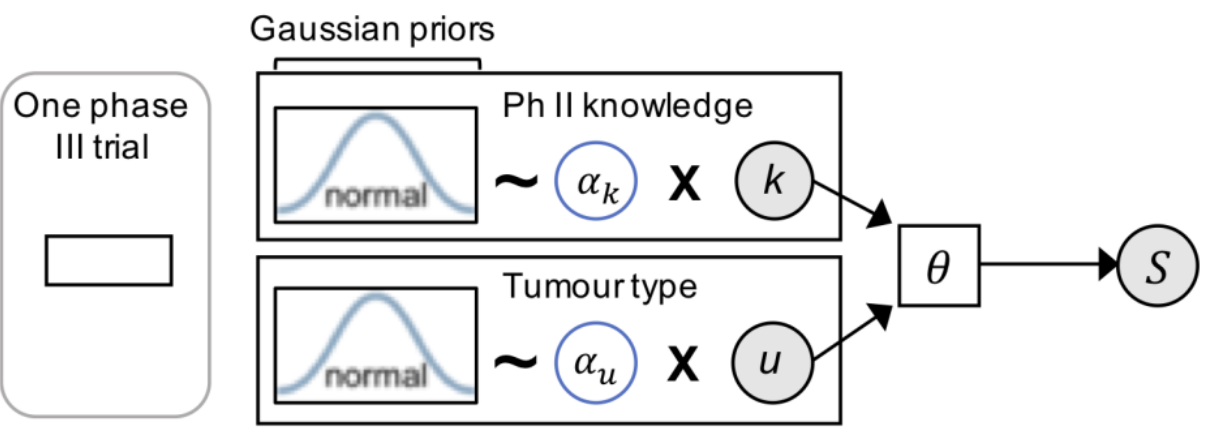

Optimisation of $\alpha$ with MCMC

B Samples from the posteriors

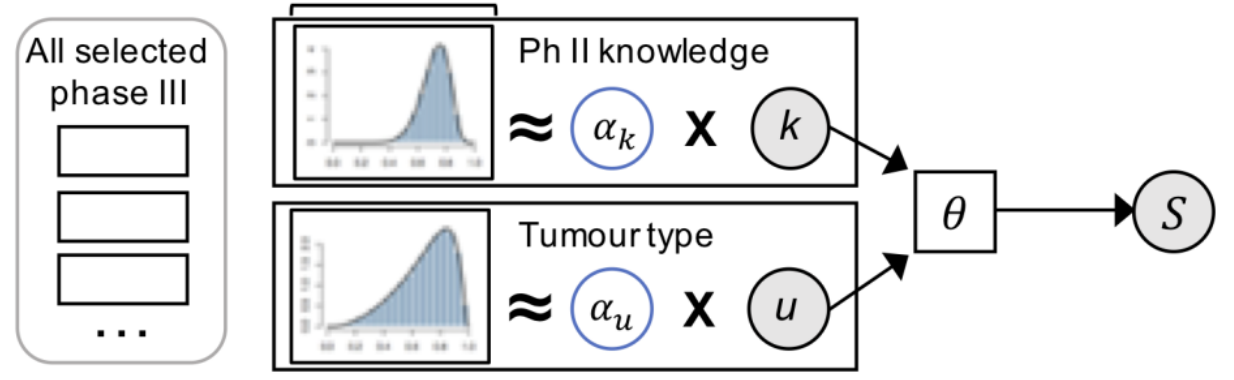

New data

C Posterior means
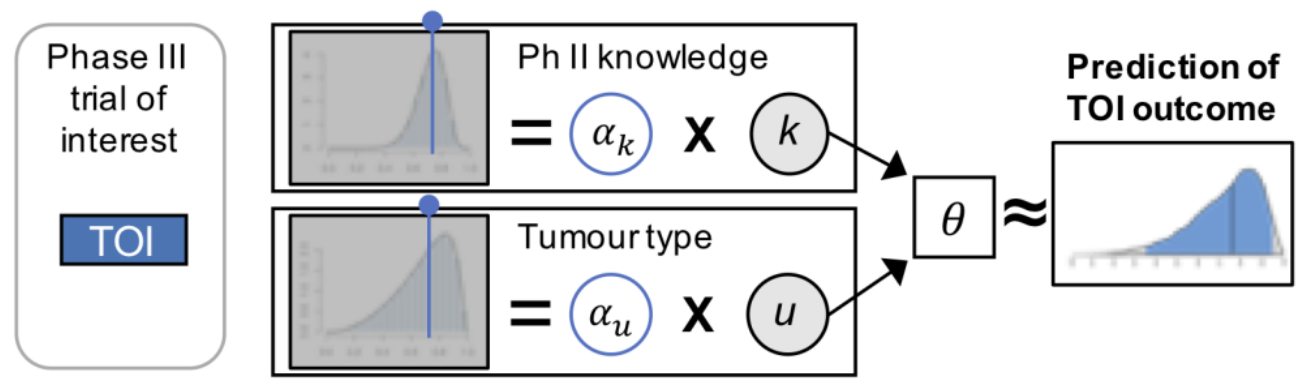

530 Schematic representation of Bayesian logistic regression. (A) Starting point: Bayesian model

531 without assumptions about the parameters. (B) Model training: samples from the posteriors

532 gained from Markov chain Monte Carlo (MCMC). (C) Calculation of PoS ${ }_{\text {Tol }}$ for ongoing or 533 planned Phlll trial. 
medRxiv preprint doi: https://doi.org/10.1101/2020.12.15.20248240; this version posted December 16, 2020. The copyright holder for this preprint (which was not certified by peer review) is the author/funder, who has granted medRxiv a license to display the preprint in It is made available under a CC-BY 4.0 International license.

\section{Figure 4}

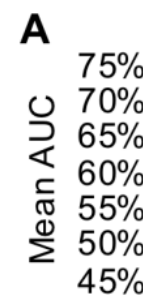

B

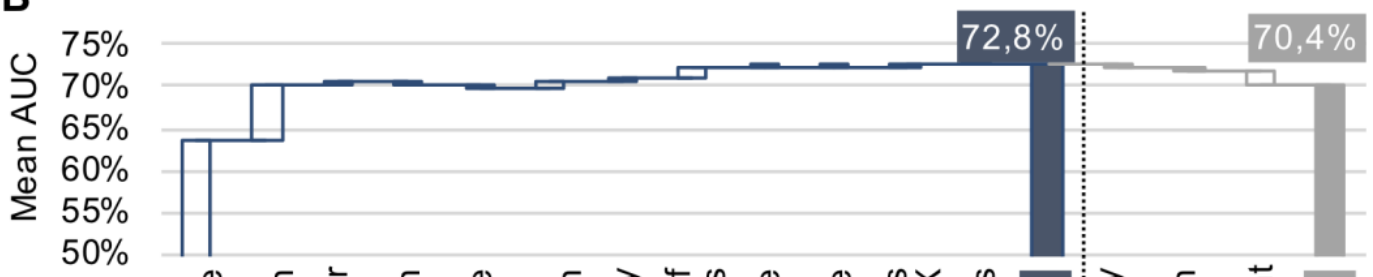

C
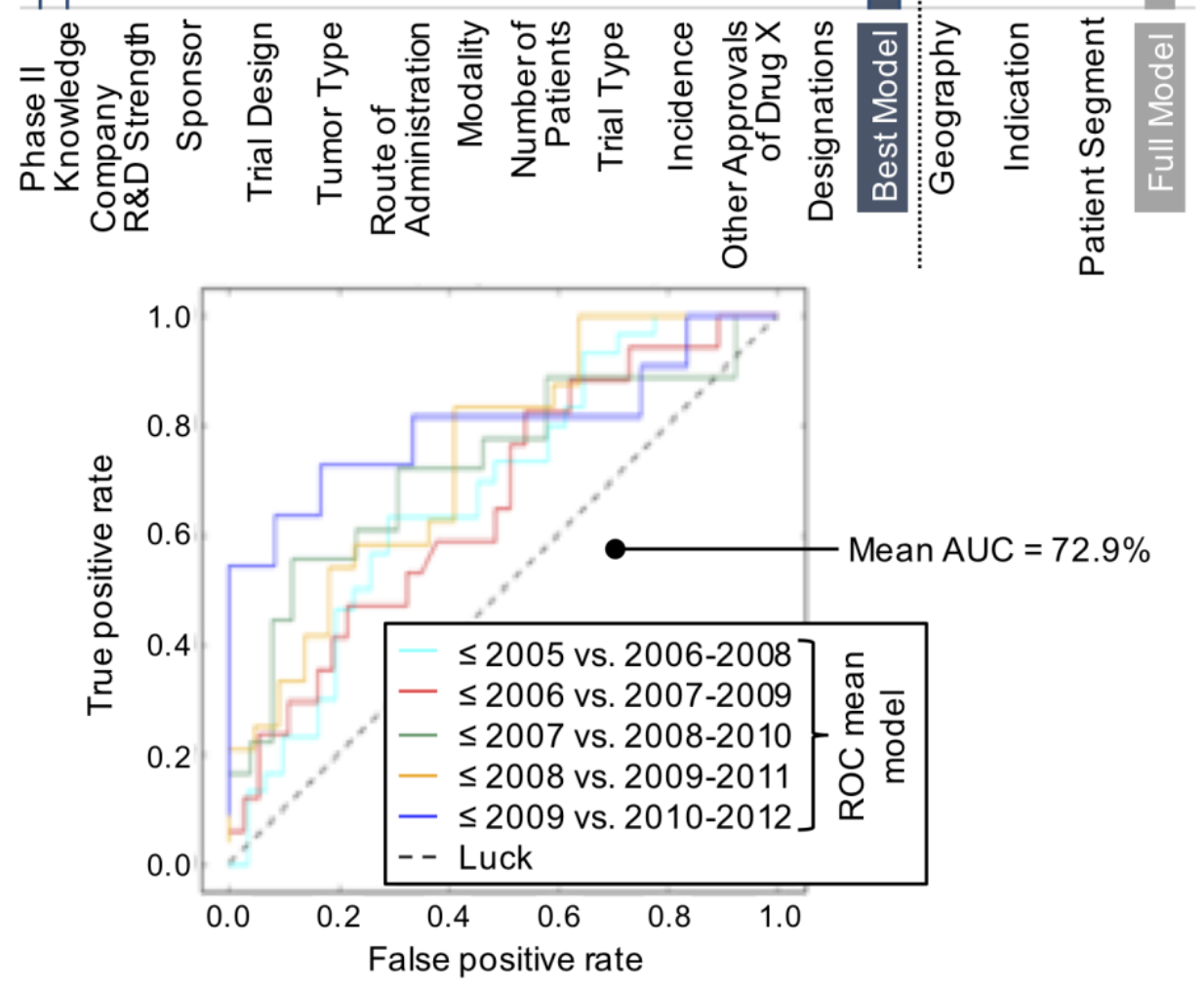

537 Model calibration and evaluation of performance. (A) AUC analysis of single-variables. The

538 greater the distance from AUC $=0.5$ (dotted line), the stronger the predictive performance of

539 the variable. (B) At each step, the composite score performing best in combination with the

540 intermediate model is selected. The predictive performance is at its maximum after the

541 inclusion of 12 composite scores. The composite scores geography, indication, and patient 
medRxiv preprint doi: https://doi.org/10.1101/2020.12.15.20248240; this version posted December 16, 2020. The copyright holder for this preprint (which was not certified by peer review) is the author/funder, who has granted medRxiv a license to display the preprint in It is made available under a CC-BY 4.0 International license.

542 segment are not included in the model because they fail to increase its performance. (C) For

543 the best model, the receiver operating characteristic curves are displayed for each time

544 series. The overall model performance is given by the mean AUROC over all time points and 545 is $\sim 73 \%$.

546 
medRxiv preprint doi: https://doi.org/10.1101/2020.12.15.20248240; this version posted December 16, 2020. The copyright holder for this preprint (which was not certified by peer review) is the author/funder, who has granted medRxiv a license to display the preprint in It is made available under a CC-BY 4.0 International license.

\section{Figure 5}

A

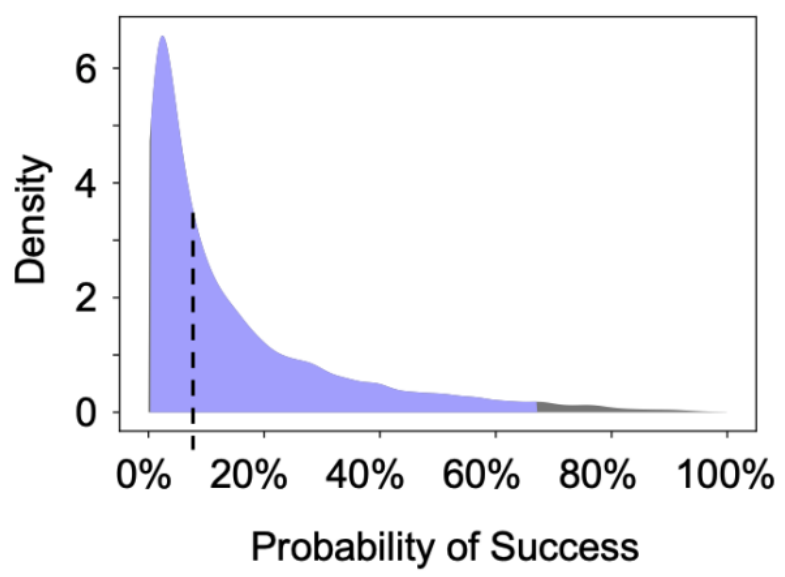

C

JClin Oncol. 2017 Jul 10;35(20):2279-2287. doi: 10.1200/JCO.2016.70.3934. Epub 2017 May 24 Gefitinib and EGFR Gene Copy Number Aberrations in Esophageal Cancer.
B

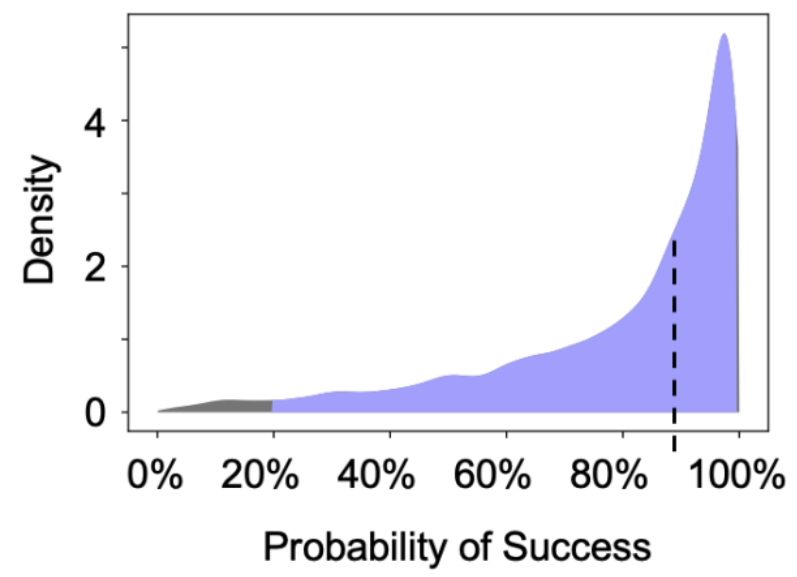

D

Lancet Oncol. 2017 Jun;18(6):732-742. doi: 10.1016/S1470-2045(17)30312-1. Epub 2017 May 16. Trastuzumab emtansine versus capecitabine plus lapatinib in patients with previously treated HER2-positive advanced breast cancer (EMILIA): a descriptive analysis of final overall survival results from a randomised, open-label, phase 3 trial.
548

549

550

551

552

553

554

555

556

Selected PoS distributions. (A) The 13 composite scores selected for the model and the 58

variables making up those scores (unnamed for clarity) are displayed for two exemplary

clinical trials. The variables characterizing each trial are marked by a dot. The variables' weight is color coded: hue conveys the sign and intensity the amplitude. Blue indicates a positive influence on PoS prediction, red a negative one, and white no influence. (B) Study 1: The predicted PoS of the phase III trial in esophageal cancer with gefitinib (NCT01243398) is $7.8 \%$ pos (dotted line) and the $95 \% \mathrm{cl}$ credible interval ranges from $0.3 \%$ pos to $67.2 \%$ pos (colored area under the curve). (C) Study 2: The predicted PoS of the phase III trial in breast cancer with trastuzumab emtansine (NCT00829166) is $88.6 \%$ pos and the $95 \%$ cl credible interval ranges from $19.6 \%$ pos to $99.6 \%$ pos. The predicted PoS for those two studies are consistent with results published in peer-reviewed articles: the study with gefitinib failed (D), while the study with trastuzumab emtansine was successful (E). 